\title{
Opsonic monoclonal antibodies against lipopolysaccharide antigens of Leptospira interrogans serovar hardjo
}

\author{
H. E. FARRELLY, B. ADLER and S. FAINE
}

Department of Microbiology, Monash University, Clayton, 3168, Victoria, Australia

\begin{abstract}
Summary. Six monoclonal antibodes produced from mice immunised with Leptospira interrogans serovar hardjo were directed against determinants in the leptospiral lipopolysaccharide, as indicated by immunodiffusion and enzyme immunoassay (EIA), and opsonised leptospires for phagocytosis by mouse macrophages. Their specificities were studied by agglutination and EIA. Five antibodies reacted with some, but not all, members of the Sejroe and Hebdomadis serogroups, and one antibody agglutinated exclusively members of the Sejroe group thus indentifying a serogroupspecific epitope. None of the six antibodies reacted with representative serovars of any other serogroup.
\end{abstract}

\section{Introduction}

Leptospirosis is an acute febrile septicaemic illness caused by Leptospira interrogans. Immunity to leptospirosis is humorally mediated (Adler and Faine, 1976, 1977, 1978; Adler et al., 1980a) and although the importance of agglutinating antibodies in immunity has been well established, the nature and identity of the corresponding leptospiral antigens have not been well studied.

Many different antigenic preparations extracted from leptospires (Faine, 1974) have been described and classified according to seroreactions such as agglutination, complement fixation or precipitation, or in terms of their specificities as serovar- or serogroup-specific. However, these preparations are generally complex mixtures of antigens, about whose individual specificities and properties there is little information. The use of monoclonal antibodies provides a new approach.

Recently, Adler and Faine (1983a) reported the production of a species-specific monoclonal antibody that was directed against an antigen or epitope common to pathogenic serovars of leptospires but not found on the saprophytic L. biflexa nor L. illini. This antibody was not agglutinating, suggesting a sub-surface location for the antigen, and showed no activity in opsonisation and hamster protection tests, thus precluding a role for the antigen in immunity to leptospirosis. However, the taxonomic significance is obvious.

Received 20 Jan. 1986; accepted 16 Apr. 1986
Adler and Faine (1983b) identified an epitope, present only in leptospires of the Pomona serogroup, which was one of at least two antigenic determinants recognised on lipopolysaccharide (LPS) from serovar pomona.

Ono et al. (1982) produced monoclonal antibodies to LPS (TM antigen) of serovar kremastos. These showed various cross reactivities in agglutination tests and were classified into 10 distinct groups on the basis of their serological specificity, indicating that TM antigen from serovar kremastos contained at least 10 different epitopes. They also produced five anti-canicola TM antigen antibodies which showed three distinct reactivities for the 11 serovars in the Canicola serogroup.

In the present paper we report the characterisation of opsonic monoclonal antibodies reactive against the LPS antigen or serovar hardjo.

\section{Methods and methods}

\section{Organisms}

Leptospira illini serovar illini and L. biflexa serovar patoc were obtained from A. D. Alexander, Walter Reed Army Medical Center, Washington D.C., USA. Serovar hardjo strain 171 was a bovine isolate obtained from $\mathrm{R}$. B. Marshall, Massey, University, New Zealand. All other serovars of leptospires were provided by N. Stallman, W.H.O. Leptospira Reference Laboratory, Brisbane, Australia. The serogroups of $L$. interrogans used are listed with the serovars in parentheses: Australis (australis); Autumnalis (autumnalis); Ballum (ballum); Bataviae (bataviae); Butembo (butembo); Canicola (canicola); Cel- 
ledoni (celledoni); Cynopteri (cynopteri); Djasiman (djasiman); Grippotyphosa (grippotyphosa); Icterohaemorrhagiae (copenhageni); Javanica (javanica); Panama (panama); Pyrogenes (zanoni); Tarassovi (tarassovi). Leptospires were grown in Tween albumin EMJH medium with added pyruvate (Johnson et al., 1973) and were enumerated in a Thoma bacterial counting chamber.

\section{Sera, antigens and serological methods}

The preparation of mouse antisera against whole leptospires was described previously (Tu et al., 1982) as were the methods for the microscopic agglutination test (MAT) (Adler and Faine, 1976), immunodiffusion tests (Faine et al., 1974) and the enzyme immunoassay (EIA) (Adler and Faine, 1983b). Leptospiral sonicate antigens were prepared as described previously (Adler et al., $1980 b$ ) and leptospiral LPS was prepared according to the method of Westphal and Jann (1965) with a final step consisting of centrifugation at $105000 \mathrm{~g}$ for $3 \mathrm{~h}$.

\section{Production of monoclonal antibodies}

Adult Balb/c mice were immunised with an intraperitoneal injection of $2.5 \times 10^{8}$ leptospires of $L$. interrogans serovar hardjo (Hardjoprajitno reference strain) grown in protein-free medium (Christopher et al., 1982) and were given a booster injection after 1 month. Three days later spleen cells were harvested into Dulbecco Modified Eagle's Medium (DME, Microbiological Associates, Bethesda, MD, USA). The polyethylene glycol method described by Kohler and Milstein (1975) was used to fuse $10^{8}$ spleen cells with $10^{7} \mathrm{NS}-1$ mouse myeloma cells. Resultant hybridomas were grown, screened for antileptospiral antibody by MAT and EIA, and cloned by limiting dilution as described previously (Adler and Faine, 1983b). All hybridomas were cloned at least twice and then grown to the required volume (usually $1000 \mathrm{ml}$ ) in DME. Culture supernates containing antibody were obtained by centrifugation and concentrated by ultrafiltration. The final antibody concentration was $0.5-1.0 \mathrm{mg} /$ $\mathrm{ml}$. Isotypes of antibodies were determined by immunodiffusion with specific rabbit antisera (Nordic Laboratories, Tilburg, The Netherlands).

\section{Opsonisation and phagocytosis}

Mouse peritoneal macrophages were harvested as described previously (Tu et al., 1982) and were incubated for $1 \mathrm{~h}$ at $37^{\circ} \mathrm{C}$ in a humidified $\mathrm{CO}_{2}$ incubator in $1 \mathrm{ml}$ of DME containing fetal calf serum $10 \% \mathrm{v} / \mathrm{v}$ (DME-FCS) in glass chemiluminescence (CL) vials (for CL assays), or in Leighton tubes with glass cover slips (for immunofluorescence), at a concentration of $10^{6}$ macrophages $/ \mathrm{ml}$. When required, $10-\mu \mathrm{l}$ volumes of monoclonal antibodies or mouse anti-hardjo serum at subagglutinating concentrations (such that the final dilution was double the MAT titre) or normal mouse serum or DME-FCS (final dilution 1 in 100) were added to CL vials, followed by leptospires at a ratio of 100/macrophage. CL measure- ments were performed as described previously (McGrath et al., 1984). For immunofluorescence, $10^{8}$ leptospires were incubated with $10^{6}$ macrophages for $30 \mathrm{~min}$ at $37^{\circ} \mathrm{C}$, the monolayers washed with phosphate-buffered saline $p \mathrm{H} 7 \cdot 2$ (PBS), fixed for $10 \mathrm{~min}$ in formalin $10 \% \mathrm{v} / \mathrm{v}$ in PBS, and washed three times in PBS. Phagocytosed leptospires were visualised by indirect immunofluorescence staining and examination with a Zeiss IM35 inverted epifluorescence microscope. Mouse anti-hardjo serum was used as the primary antibody (Tu et al., 1982) and FITCconjugated rabbit anti-mouse serum as the second antibody (Antibodies Inc., Davis, CA, USA).

\section{Electrophoresis, transblotting and staining}

Sonicated leptospires ( $20 \mu \mathrm{g}$ of protein $/ 6-\mathrm{mm}$ lane) or LPS ( $5 \mu \mathrm{g} /$ lane) were electrophoresed on $1.5 \mathrm{~mm}$ thick, discontinuous sodium dodecyl sulphate polyacrylamide $15 \% \mathrm{w} / \mathrm{v}$ gels (SDS-PAGE) as described by Laemmli (1970), in a Protean I gel apparatus (Bio-Rad, Richmond, CA, USA). Gels were silver stained for LPS as described by Hitchcock and Brown (1983). Resolved material was transblotted (Burnette, 1981) on to nitrocellulose paper (Schleicher and Schuell, pore size $0.45 \mu \mathrm{m}$ ) in a BioRad transblot cell, and immunostained with monoclonal antibodies, peroxidase-conjugated rabbit anti-mouse serum (Silenus Laboratories, Dandenong, Australia), and 4-chloro-naphthol as described by Hawkes et al. (1982).

\section{Results}

\section{Isotypes of monoclonal antibodies}

The isotypes of the six antibodies reported in this paper (MUM/F1-1 to F1-6/hardjo), determined by immunodiffusion with specific rabbit antisera, are shown in table I.

\section{Serological specificities of monoclonal antibodies}

The serovar specificities of monoclonal antibodies were determined by MAT and EIA (table I). The antibodies varied in their agglutination reactions with serovars of the Sejroe serogroup of $L$. interrogans, reacting with some, but not all, serovars. F1-3, F1-5 and F1-6 agglutinated all serovars of the Sejroe group except rupa rupae; the other three antibodies varied in their specificities. The antibodies showed large differences in their specificities by MAT for members of the closely related Hebdomadis serogroup, from F1-6, that failed to agglutinate any serovars in this group, to F1-2 that agglutinated all members except goiano and maru.

There was little difference in the reactions of the antibodies with the bovine strain hardjo 171 compared with the Hardjoprajitno reference strain 
Table I. Cross reactions of monoclonal antibodies F1-1 to F1-6 with serovars of the Sejroe and Hebdomadis serogroups of $L$. interrogans as measured by microscopic agglutination test (MAT) and enzyme immunoassay (EIA)

\begin{tabular}{|c|c|c|c|c|c|c|c|c|c|c|c|c|}
\hline \multirow[b]{3}{*}{ Serovar } & \multicolumn{12}{|c|}{ Reactions with monoclonal antibody (and isotype) } \\
\hline & \multicolumn{2}{|c|}{$\begin{array}{c}F 1-1 \\
\text { (IgG1) }\end{array}$} & \multicolumn{2}{|c|}{$\begin{array}{c}\text { F1-2 } \\
(\mathrm{IgM})\end{array}$} & \multicolumn{2}{|c|}{$\begin{array}{c}\text { F1-3 } \\
\text { (IgG3) }\end{array}$} & \multicolumn{2}{|c|}{$\begin{array}{c}\mathrm{FI}-4 \\
(\mathrm{IgM})\end{array}$} & \multicolumn{2}{|c|}{$\begin{array}{c}\text { F1-5 } \\
\text { (IgM) }\end{array}$} & \multicolumn{2}{|c|}{$\begin{array}{c}\text { F1-6 } \\
\text { (IgG3) }\end{array}$} \\
\hline & MAT* $^{*}$ & $\mathrm{EIA}_{\dagger}^{\dagger}$ & MAT & EIA & MAT & EIA & MAT & EIA & MAT & EIA & MAT & EIA \\
\hline SEJROE group & & & & & & & & & & & & \\
\hline balcanica & 512 & 66 & 256 & 235 & 32 & 57 & 128 & 67 & 256 & 79 & 512 & 87 \\
\hline caribe & 256 & 76 & 2048 & 505 & 1024 & 97 & 2048 & 134 & 2048 & 174 & 512 & 182 \\
\hline dikkeni & - & - & 2048 & 270 & 256 & - & - & - & 32 & - & 16 & - \\
\hline geyaweera & - & - & 256 & 550 & 32 & 135 & - & - & 2048 & 189 & 1024 & - \\
\hline gorgas & 16 & - & 4096 & 595 & 256 & 135 & 256 & 53 & 1024 & 179 & 4096 & 146 \\
\hline guaricurus & 64 & 30 & 512 & 475 & 128 & 82 & 512 & 119 & 128 & 125 & 64 & 154 \\
\hline haemolytica & - & - & 2048 & 590 & 64 & 170 & 8 & 103 & 128 & 227 & 8 & - \\
\hline Hardjoprajitno & 512 & 100 & 256 & 100 & 128 & 100 & 256 & 100 & 2048 & 100 & 2048 & 100 \\
\hline hardjo 171 & 2 & 16 & 512 & 110 & 256 & 93 & 1024 & 17 & 2048 & 64 & 512 & 95 \\
\hline istrica & 128 & - & 2048 & 485 & 128 & 85 & 1024 & 38 & 512 & 26 & 256 & 100 \\
\hline medanensis & 1024 & - & 1024 & 85 & 256 & - & 256 & 38 & 2048 & 49 & 2048 & 62 \\
\hline nyanza & 128 & - & 2 & 535 & 2048 & 150 & - & 148 & 2 & 229 & 1024 & 177 \\
\hline polonica & - & - & - & 595 & 512 & 141 & 2048 & 100 & 2048 & 85 & 1024 & 256 \\
\hline recreo & 256 & - & 2048 & 545 & 256 & 140 & - & - & 512 & 179 & 256 & 118 \\
\hline ricardi & 2 & - & 512 & 560 & 32 & 136 & - & - & 16 & 191 & 16 & -- \\
\hline roumanica & 128 & - & 1024 & 570 & 256 & 166 & 2048 & 122 & 1024 & 197 & 128 & 277 \\
\hline rupa rupae & - & - & - & - & - & - & - & - & - & - & - & - \\
\hline saxkoebing & - & - & 2048 & 95 & 128 & - & - & - & 4 & - & 64 & - \\
\hline sejroe & - & - & - & 90 & 256 & - & 1024 & - & 1024 & - & 256 & - \\
\hline trinidad & - & 130 & 8 & 585 & 128 & 148 & 512 & 163 & 128 & 191 & 128 & 303 \\
\hline wolffi & 2048 & 42 & 256 & - & 512 & - & 1024 & 34 & 2048 & 38 & 256 & - \\
\hline HEBDOMADIS grou & & & & & & & & & & & & \\
\hline & - & - & 512 & 440 & 8 & - & 32 & 90 & 512 & 179 & - & - \\
\hline borincana & - & - & 128 & 260 & - & - & 16 & 62 & 128 & 85 & - & - \\
\hline georgia & - & - & 256 & 520 & 2 & 32 & 4 & 136 & 512 & 174 & - & - \\
\hline goiano & - & - & - & - & - & - & - & - & - & - & - & - \\
\hline hebdomadis & - & - & 512 & 90 & - & - & 128 & - & 256 & - & - & - \\
\hline jules & - & - & 2048 & 140 & - & - & - & - & - & - & - & - \\
\hline kabura & - & - & 2048 & 330 & - & - & 2048 & 72 & 1024 & 117 & - & - \\
\hline kambale & 2 & - & 1024 & - & - & - & - & - & - & - & - & - \\
\hline kremastos & 2 & - & 512 & - & - & - & 512 & - & 256 & 43 & - & - \\
\hline maru & - & - & - & - & - & - & - & - & - & - & - & \\
\hline $\min i$ & - & - & 1024 & - & 2 & - & 4 & - & 512 & - & - & - \\
\hline nona & - & - & 512 & - & - & - & - & - & - & - & - & - \\
\hline parameles & - & - & 128 & 525 & - & - & 128 & 164 & 64 & 145 & - & - \\
\hline szwajizak & - & - & 128 & - & 4 & - & - & - & 128 & - & - & - \\
\hline tabaquite & - & - & 512 & - & 4 & - & 512 & - & - & 17 & - & - \\
\hline worsfoldi & - & - & 2048 & 395 & - & - & - & - & - & - & - & - \\
\hline
\end{tabular}

* MAT. Titre expressed as the highest dilution showing agglutination.

$\dagger$ EIA. Results expressed as percentage of OD at $488 \mathrm{~nm}$ obtained by heterologous EIA compared with homologous EIA (Hardjoprajitno).

$-=$ Negative by MAT, or EIA OD < background level (0.20).

except with F1-1, which agglutinated hardjo 171 to a titre of only 2, compared with 512 for Hardjoprajitno, and F1-4 which showed a reduced reaction with hardjo 171 by EIA although the agglutination titres for the two strains were similar.

Different patterns of specificities were observed when the antibodies were tested by EIA, with most of them showing narrower specificities than by MAT. F1-1, F1-3 and F1-6 reacted with fewer serovars of the Sejroe group by EIA and neither F11 nor F1-6 reacted with any Hebdomadis serovars by EIA. Similarly, F1-2 reacted with far fewer 


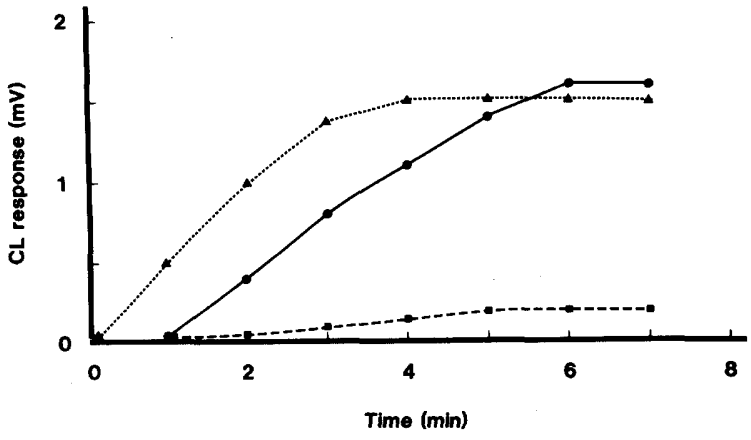

Fig. 1. Chemiluminescence (CL) reponse of $10^{6}$ mouse macrophages incubated with $10^{8}$ leptospires of serovar hardjo in normal mouse serum $\square-.--\mathbf{\square}$; mouse anti-hardjo serum; $\mathbf{\Delta} \cdots \mathbf{\Delta}$; MUM/ F1-3/hardjo monoclonal antibody

Hebdomadis serovars by EIA than it agglutinated.

None of the six monoclonal antibodies agglutinated or reacted in EIA with leptospires of serovars representative of any other serogroup (see Materials and methods) of $L$. interrogans, nor with $L$. illini nor with $L$. biflexa serovar patoc.

Opsonisation of leptospires for phagocytosis by macrophages

Opsonisation of homologous lepospires by monoclonal antibodies was measured by both chemiluminescence and immunofluorescence staining of macrophages. A CL response was observed when macrophages were incubated with homologous leptospires in the presence of each of the six monoclonal antibodies. Antibodies F1-1 to F1-6 gave peak responses, after 6-9 min, of $1 \cdot 4,2 \cdot 2,1 \cdot 6$, $0.4,0.8$ and $1.7 \mathrm{mV}$ respectively. The responses gradually declined to base levels within $25-30 \mathrm{~min}$. A typical response with antibody F1-3 and polyclonal mouse anti-hardjo serum is shown in fig. 1 . No CL response was seen in the presence of either normal mouse serum (fig. 1) or hybridoma culture medium alone.

Immunofluorescence staining of mouse macrophages following incubation with homologous leptospires showed that leptospires were phagocytosed in the presence of subagglutinating levels of each of the monoclonal antibodies or of polyclonal mouse anti-hardjo serum, but not in the presence of either normal mouse serum or hybridoma culture medium alone. Fig. 2 shows a typical result with F1-3 antibody.

\section{Reactions of monoclonal antibodies with homologous LPS}

All six monoclonal antibodies produced strong precipitin lines when tested in immunodiffusion against purified homologous (Hardjoprajitno) LPS at a concentration of $1 \mathrm{mg} / \mathrm{ml}$ (fig. 3) and all reacted strongly with LPS $50 \mu \mathrm{g} / \mathrm{ml}$ in EIA tests (table II). All six antibodies reacted with purified LPS by immunoblotting, with a characteristic immuno-

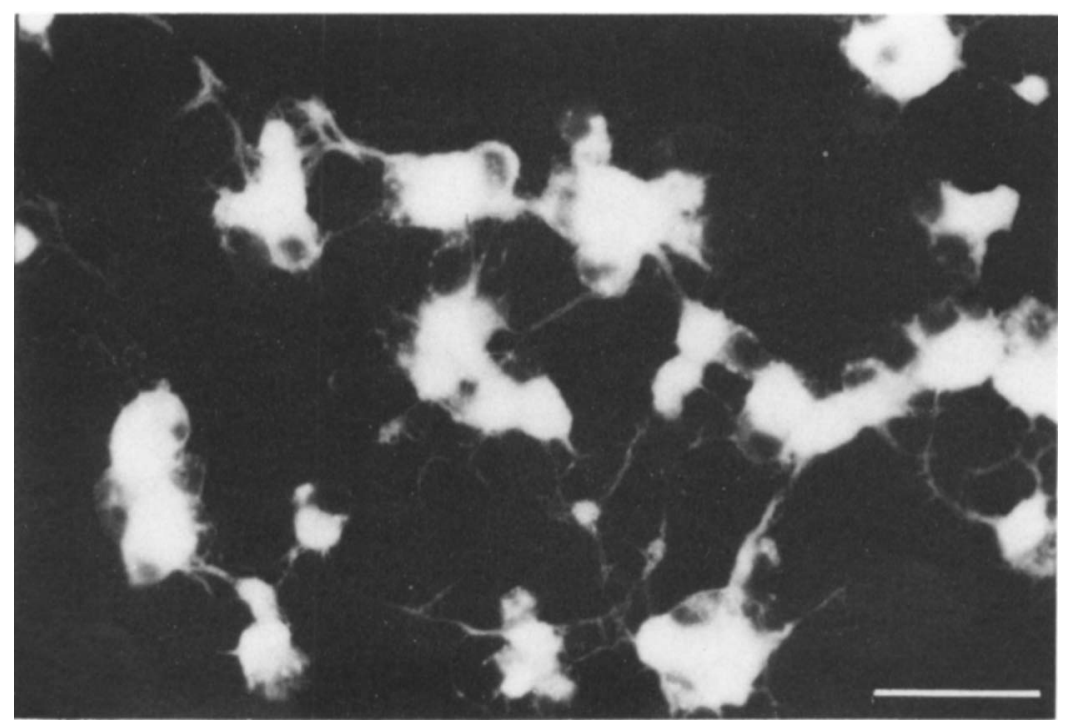

Fig. 2. Immunofluorescence staining of mouse macrophages incubated with leptospires of serovar hardjo and MUM/F1-3/hardjo monoclonal antibody, showing ingestion of leptospires after opsonisation. Bar $=20 \mu \mathrm{m}$. 


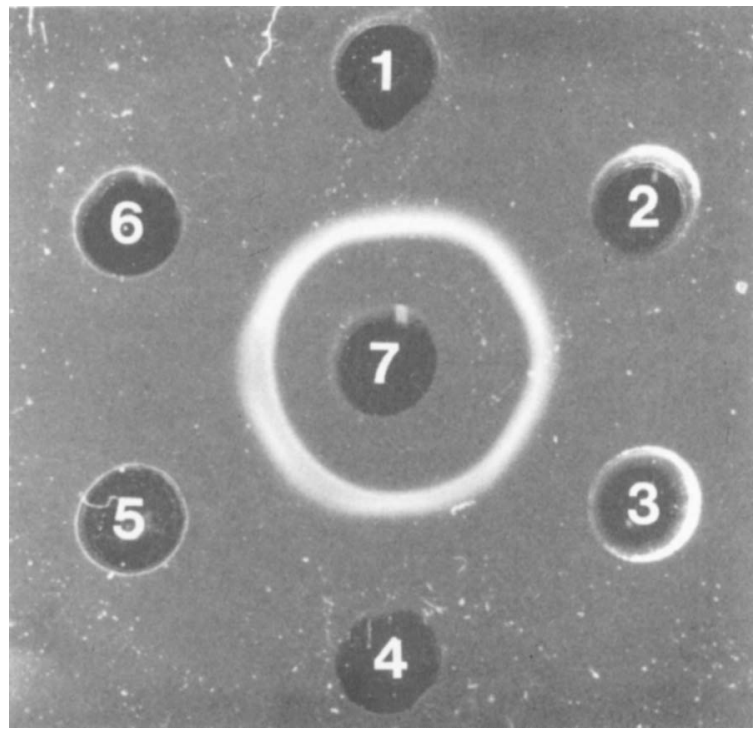

Fig. 3. Immunodiffusion reactions of monoclonal antibodies MUM/F1-1 to F1-6/hardjo (wells 1-6 respectively) with homologous LPS (well 7).

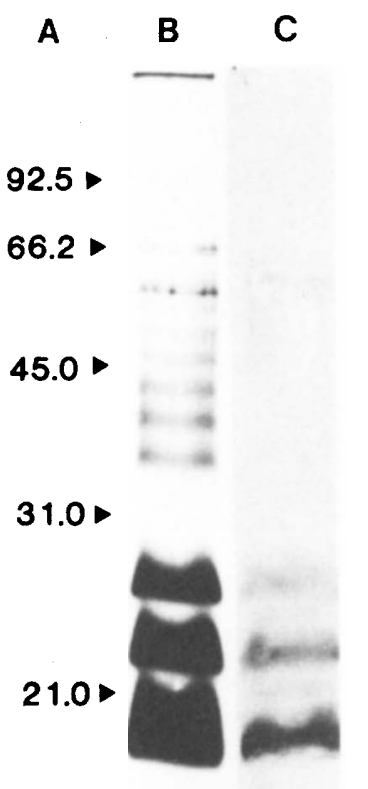

14.4•
Table II. Reactivity of monoclonal antibodies F1-1 to F1-6 with homologous LPS as measured by enzyme immunoassay

\begin{tabular}{l|rrr}
\hline & \multicolumn{3}{|c}{$\begin{array}{l}\text { Absorbance values* at 488 nm } \\
\text { with antigen preparation } \dagger\end{array}$} \\
\cline { 2 - 4 } Test antibody $\ddagger$ & $\begin{array}{c}\text { hardjo } \\
\text { sonicate }\end{array}$ & $\begin{array}{c}\text { hardjo } \\
\text { LPS }\end{array}$ & $\begin{array}{c}\text { pomona } \\
\text { sonicate }\end{array}$ \\
\hline mouse normal serum & 0.14 & 0.13 & 0.11 \\
mouse antiserum & $>2.00$ & 1.59 & 0.78 \\
F1-1 & $>2.00$ & $>2.00$ & 0.07 \\
F1-2 & 1.76 & 1.50 & 0.05 \\
F1-3 & $>2.00$ & $>2.00$ & 0.12 \\
F1-4 & 1.78 & 1.36 & 0.11 \\
F1-5 & 1.84 & 1.57 & 0.05 \\
F1-6 & $>2.00$ & 1.69 & 0.14 \\
\end{tabular}

* An absorbance value of $>0.20$ was considered positive.

$\dagger$ LPS was used at $50 \mu \mathrm{g} / \mathrm{ml}$ and sonicates were used at $5 \times 10^{7}$ leptospires $/ \mathrm{ml}$.

$\ddagger$ Monoclonal antibodies were tested at a dilution of 1 in 5 and polyclonal mouse anti-hardjo serum and normal mouse serum were used at a dilution of 1 in 100 .
Fig. 4. SDS PAGE patterns of $L$. interrogans serovar hardjo LPS. Lane A: positions of mol. wt markers $\left(10^{3}\right)$; lane B: silver stain of hardjo LPS; lane C: immunostain of lane B with MUM/ F1-1/hardjo.

staining pattern of three major bands as shown with the example of antibody F1-1 in fig. 4 .

\section{Discussion}

Six monoclonal antibodies against $L$. interrogans serovar hardjo were produced. These antibodies showed different cross-reactivities with serovars of the Sejroe and Hebdomadis serogroups by both agglutination and enzyme immunoassay, indicating that they were directed against different epitopes. The epitope against which antibody MUM/F1-6/ hardjo was directed was found exclusively in all serovars of the Sejroe group except rupa rupae, indicating that this serovar, which has been only provisionally included in this serogroup (Faine, 
1982; de Hidalgo and Sulzer, 1984; Johnson and Faine, 1984) may need further evaluation.

Antibodies F1-2 to F1-6 agglutinated the field isolate of serovar hardjo 171 with titres not significantly different from those against the hardjoprajitno reference strain used as the immunogen. However, F1-1 identified quantitative differences between Hardjoprajitno and hardjo 171, in that it hardly agglutinated the field strain at all (MAT titre, 2). Quantitative differences were also detected by EIA, with hardjo 171 reacting to only $16 \%$ and $17 \%$ of the homologous reactions with antibodies F1-1 and F1-4 respectively, indicating greatly reduced amounts of the corresponding epitopes in the field strain. Differences in epitopes between laboratory reference strains and field strains have obvious implications for serodiagnosis and the selection of vaccine strains. In particular, many workers consider that Hardjoprajitno and the serovar hardjo strains currently prevalent as world-wide causes of human and animal infections are different subtypes (Ellis, 1985), and these two strains have been distinguished on the basis of DNA restriction endonuclease analysis (Robinson et al., 1982). Our finding with Fl-1 monoclonal antibody is the first documented antigenic difference between these strains.

All six monoclonal antibodies reacted with purified homologous LPS by immunodiffusion, EIA and in western blots indicating that LPS from serovar hardjo contains at least six different antigenic determinants. The fact that all six react with the three major bands in LPS shows that the different epitopes are to be found on identical structural LPS components, On the basis of the F1-6 reactive epitope which was an LPS component present only in serovars of the Sejroe serogroup, the results also confirm the recently agreed separation of Sejroe and Hebdomadis serogroups. Our results are similar to those of Ono et al. (1982) who found at least 10

\section{REFERENCES}

Adler B, Faine S 1976 Susceptibility of mice treated with cyclophosphamide to lethal infection with Leptospira interrogans serovar pomona. Infection and Immunity 14:703-708.

Adler B, Faines S 1977 Host immunological mechanisms in the resistance of mice to leptospiral infection. Infection and Immunity 17:67-72.

Adler B, Faine S 1978 The antibodies involved in the human immune response to leptospiral infection. Journal of Medical Microbiology 11:387-400.

Adler B, Faine S $1983 a$ Species-specific and genus-specific antigens in Leptospira, revealed by monoclonal antibodies and enzyme immunoassay. Zentralblatt für Bakteriologie Mikrobiologie und Hygiene 1 Abteilung Originale A 255:317322. antigenic determinants on serovar kremastos TM (LPS) antigen, and at least three determinants on serovar canicola TM antigen, and the results of Adler and Faine (1983a) who found at least two different epitopes on LPS from serovar pomona. In all of these serovars more epitopes may be identified if more monoclonal antibodies of different specificities are produced.

Although several groups of workers have now used monoclonal antibodies against leptospires, the corresponding epitopes have been described mainly for their taxonomic or diagnostic interest and have not been examined for their potential roles as identified antigens involved in immunity. In our study all six monoclonal antibodies which reacted against epitopes on homologous LPS also opsonised leptospires for phagocytosis by mouse macrophages. LPS has been identified, by monoclonal antibodies, as an important protective antigen in acute infections with other gram-negative bacteria (Colwell et al., 1984; Kirkland and Ziegler, 1984; Sawada et al., 1984), but it was not possible to perform protection experiments with serovar hardjo as it does not cause lethal infections in laboratory animals. The importance of opsonisation and phagocytosis as host defence mechanisms against leptospirosis is well established (Cinco et al., 1982; Tu et al., 1982; McGrath et al., 1984) and these observations together with the opsonic activities of our monoclonal antibodies identify LPS as an important protective antigen in leptospires of serovar hardjo. The significance of LPS in immunity and prevention of leptospirosis thus requires further study.

This work was supported by a research grant from the National Health and Medical Research Council, Canberra, Australia. We thank Tu Vinh for assistance with the silver staining techniques.

Adler B, Faine S $1983 b$ A Pomona serogroup-specific, agglutinating antigen in Leptospira, identified by monoclonal antibodies. Pathology 15:247-250.

Adler B, Faine S, Muller H K, Green D E $1980 a$ Maturation of humoral immune response determines the susceptibility of guinea pigs to leptospirosis. Pathology 12:529-538.

Adler B, Murphy A M, Locarnini S A, Faine S $1980 b$ The detection of specific anti-leptospiral immunoglobulin $\mathbf{M}$ and immunoglobulin $G$ in human serum by solid-phase enzyme-linked immunosorbent assay. Journal of Clinical Microbiology 11:452-457.

Burnette W N 1981 "Western blotting": electrophoretic transfer of proteins from sodium dodecyl sulfate-polyacrylamide gels to unmodified nitrocellulose and radiographic detection with antibody and radioiodinated Protein A. Analytical Biochemistry 112:195-203. 
Christopher W L, Adler B, Faine S 1982 Immunogenicity of leptospiral vaccines grown in protein-free medium. Journal of Medical Microbiology 15:493-501.

Cinco M, Banf E, Soranzo M R 1981 Studies on the interaction between macrophages and leptospires. Journal of General Microbiology 124:409-413.

Colwell D E, Michalek S M, Briles D E, Jirillo E, McGhee J R 1984 Monoclonal antibodies to Salmonella lipopolysaccharide: anti-O-polysaccharide antibodies protect $\mathrm{C} 3 \mathrm{H}$ mice against challenge with virulent Salmonella typhimurium. Journal of Immunology 133:950-957.

de Hidalgo J L, Sulzer K R 1984 Six new leptospiral serovars isolated from wild animals in Peru. Journal of Clinical Microbiology 19:944-045.

Ellis W A 1985 Restriction endonuclease techniques in the study of the epidemiology of serovar hardjo. Abstracts of the 5th meeting of European Leptospira workers, Amsterdam, 1985.

Faine S 1974 Leptospiral antigens. Folia Facultatis Medicae Universitatis Comeninae Bratislavensis. 12:57-74.

Faine S (ed) 1982 Guidelines for the control of leptospirosis. WHO Offset Publication No. 67, World Health Organization, Geneva.

Faine S, Adler B, Palit A 1974 Chemical, serological and biological properties of a serotype-specific polysaccharide antigen in Leptospira. Australian Journal of Experimental Biology and Medical Science 52:311-319.

Hawkes R, Niday E, Gordon J 1982 A dot-immunobinding assay for monoclonal and other antibodies. Analytical Biochemistry 119:142-147.

Hitchcock P J, Brown T M 1983 Morphological heterogeneity among Salmonella lipopolysaccharide chemotypes in silverstained polyacrylamide gels. Journal of Bacteriology 154:269-277.

Johnson R C, Faine, S 1984 Leptospira Noguchi, 1917. In: Krieg N R, Holt J G (eds) Bergey's manual of systematic bacteriology, 9 th edn. Williams and Wilkins, Baltimore, pp $62-67$.
Johnson R C, Walby J, Henry R A, Auran N E 1973 Cultivation of parasitic leptospires: effect of pyruvate. Applied Microbiology 26:1 18-119.

Kirkland T N, Ziegler E J 1984 An immunoprotective monoclonal antibody to lipopolysaccharide. Journal of Immunology 132:2590-2592.

Kohler G, Milstein C 1975 Continuous cultures of fused cells secreting antibody of predefined specificity. Nature 256:495-497.

Laemmli U K 1970 Cleavage of structural proteins during the assembly of the head of bacteriophage T4. Nature 227:680 685.

McGrath H, Adler B, Vinh T, Faine S 1984 Phagocytosis of virulent and avirulent leptospires by guinea-pig and human polymorphonuclear leukocytes in vitro. Pathology 16:243249.

Ono E, Naiki M, Yanagawa R 1982 Production and characterization of monoclonal antibodies to lipopolysaccharide antigen of Leptospira interrogans serovar kremastos and canicola. Zentralblatt für Bakteriologie Microbiologie und Hygiene 1 Abteilung Originale A 252:414-424.

Robinson A J, Ramadass P, Lee A, Marshall R B 1982 Differentiation of subtypes within Leptospira interrogans serovars hardjo, balcanica and tarassovi, by bacterial restriction-endonuclease DNA analysis (BRENDA). Journal of Medical Microbiology 15:331-338.

Sawada S, Suzuki M, Kawamura T, Fujinaga S, Masuho Y, Tomibe K 1984 Protection against infection with Pseudomonas aeruginosa by passive transfer of monoclonal antibodies to lipopolysaccharides and outer membrane proteins. Journal of Infectious Diseases 150:570-576.

Tu V, Adler B, Faine S 1982 The role of macrophages in the protection of mice againt leptospirosis: in vitro and in vivo studies. Pathology 14:463-468.

Westphal O, Jann K 1965 Bacterial lipopolysaccharides. Extraction with phenol-water and further applications of the procedure. Methods in Carbohydrate Chemistry 5:83-91. 